\title{
Evaluation of Anesthesia- and Anesthesiologist- Related Knowledge and Anxiety Levels of Patients Admitted to the Anesthesia Outpatient Clinic: An Example of Town State Hospital
}

\section{Öz}

Amaç: Bu çalışma ile ikinci basamak bir ilçe devlet hastanesinde ameliyat olacak hastalarda anestezi bilgi ve kaygı düzeylerinin belirlenmesi amaçlandı.

Yöntem: Ağustos 2019-Subat 2020 tarihleri arasında preoperatif muayene amacıyla anestezi polikliniğine başvuran 18-90 yaş arası 300 hastaya 34 soruluk bir anket uygulandı. Anket demografik veriler, anestezi bilgisi ve kaygııı ve anestezi uzmanı bilgisi olmak üzere üç bölümden oluşmaktadir.

Bulgular: Hastaların \%46.67'si anesteziyi \%26.33'ü narkozu biliyordu. Anesteziyi kimin uyguladığı sorusuna, hastaların \%40.67'si "uzman doktor" cevabını verdi. Kadınlarda endişe seviyesinin erkeklerden daha yüksek olduğu tespit edildi ( $p=0.009$ ). Anestezi işlemi ile ilgili, hastaların \%29.67'si "hiç korkusu olmadığını" söyledi ve en fazla duyulan korku ağrı hissetmekti (\%22.67). Anestezi uzmanının sorumluluklarından en fazla bilinen "Ameliyattan önce hastayı uyutmak" (\%67.67), anestezi uzmanının hastanede görev yaptığı bölümlerden en fazla bilinen ise ameliyathaneydi (\%77.33). Anestezi uzmanının diğer görevleri hakkında bilgi seviyesi ise düşüktü.

Sonuç: Anestezi uygulamaları ve anestezi uzmanın ameliyathane ve hastanedeki rolü hakkında bilgi düzeyinin yeterli olmadığı bulundu. Hastaların anestezi bilgi seviyelerinin artırılması ve bu sayede kaygılarının azaltılması amacıyla halkın bilgilendirilmesi için yeni girişimlere ihtiyaç vardır.

Anahtar kelimeler: Anestezi, endişe, anestezi uzmanının görevleri, anket, toplum sağlık bilinci

\section{ABSTRACT}

Objective: This study aimed to determine the anesthesia-related knowledge and anxiety levels of patients undergoing surgery in a second-line county state hospital.

Method: Overall, 300 patients aged 18-90 years and admitted to an anesthesia outpatient clinic for preoperative examination between August 2019 and February 2020 answered a questionnaire comprising 34 questions. The survey consisted of three sections: including demographic data, knowledge, and anxiety concerning anesthesia, and finally knowledge about anesthesiologists.

Results: A total of $46.67 \%$ of the patients knew about anesthesia, whereas $26.33 \%$ of them knew about narcosis. Regarding the question of who performs anesthesia, $40.67 \%$ of the patients answered "specialist". Furthermore, the anxiety level in women was higher than in men $(p=0.009)$. Regarding the anesthesia procedure, $29.67 \%$ of the patients reported that they had no 'fear at all', whereas the most reported fear was pain fear in $22.67 \%$ of them. The most known responsibility of anesthesiologists was 'to put a patient to sleep before surgery' (67.67\%), whereas the most known department where anesthesiologists work was the operating room (77.33\%). The knowledge level regarding the other duties of anesthesiologists was low. Conclusion: The knowledge level regarding anesthesia practices and the role of anesthesiologists in the operating room and hospital was insufficient. New initiatives are required to inform the public to increase their anesthesia-related knowledge level, thus reducing the anxiety level of patients.

Keywords: Anesthesia, anxiety, responsibilities of anesthesiologists, questionnaire, public health awareness
Received/Geliş: 29 May 2020 Accepted/Kabul: 26 November 2020 Publication date: 29 January 2021

Cite as: Kayaalt $\mathrm{S}$. Anestezi polikliniğine başvuran hastaların anestezi ve anestezi uzmanı hakkındaki bilgi ve kaygı düzeylerinin değerlendirilmesi: Illçe devlet hastanesi örneği. JARSS 2021;29(1):40-51.

Selda Kayaalth Develi Hatice Muammer Kocatürk Devlet Hastanesi, Anesteziyoloji ve Reanimasyon Kliniği, Kayseri - Türkiye drselda@hotmail.com ORCID: 0000-0002-8176-0188 
S. Kayaaltı, Anestezi Polikliniğine Başvuran Hastaların Anestezi ve Anestezi Uzmanı Hakkındaki Bilgi ve Kaygı Düzeylerinin Değerlendirilmesi: İlçe Devlet Hastanesi Örneği

\section{GiRiş}

Dünyada 1937, Türkiye'de ise 1956 yılında uzmanlık dalı olarak kabul edilen Anesteziyoloji ve Reanimasyon bilim dalındaki gelişmeler ve yeni uygulamalar ile cerrahi alandaki başarılara katkısı yıllar içinde artmaktadır. Ayrıca anestezi uzmanlarının rolü yalnızca ameliyat odası ile sınırlı olmayıp, özellikle yoğun bakım ve ağrı alanında her geçen gün sorumlulukları ve gösterdikleri başarılar artmaktadır, ancak toplumda anestezi uzmanının görev tanımı, önemi, rolü, nerede çalıştığı hatta doktor olup olmadığı farkındaIığı azdır ${ }^{(1)}$. Ülkemizde de Şekerci ve ark. ${ }^{(2)}$ ile Ceyhan ve ark. (3) çalışmalarında, Anesteziyoloji ve Reanimasyon Bilim Dalı ve anestezi uzmanlarına ilişkin bilgi eksikliği olduğunu göstermişlerdir. Bu çalışmaların üzerinden yaklaşık 20 yıl geçmiş olmasına rağmen, toplumda anestezi ve anestezi uzmanı bilincinde beklenen artış olmadığı tahmin edilmektedir. Yurt içi ve yurt dışındaki çalışmalarda, anestezi uygulamasının alanında uzman bir doktor tarafından yapıldığını bilenlerin oranı \%20-90 arasında değişmektedir ${ }^{(4-11)}$. Bunun dışında, anestezi uygulamaları hakkında da ciddi bilgi yetersizliği, bu nedenle de anestezi korkusu yaygındır. Hastalar ameliyat öncesinde özellikle anesteziden uyanamama, masada kalma, felç olma vb. gibi korkularla karşı karşıya kalmaktadır ${ }^{(6,12)}$. Anestezi uygulamasına ve cerrahi girişime ait endişeler ve anksiyetenin perioperatif hasta yönetimini ve postoperatif iyileşmeyi olumsuz etkilediği bilinmektedir ${ }^{(13)}$.

Ülkemizde halkın anestezi/anestezi uzmanı bilgisi ile ilgili çalışmalara bakıldığında ilçe bazlı yapılmış bir çalışmanın bulunmadığı görülmüştür. Bu anket çalışması ile 2. basamak bir ilçe devlet hastanesinde preoperatif değerlendirme amacıyla anestezi polikliniğine gelen hastaların anestezi ve anestezi uzmanı ile ilgili bilgi düzeylerinin ve anestezi uygulamalarına yönelik kaygı düzeylerinin belirlenmesi ve anket sonuçlarını etkileyebilecek olan yaş, cinsiyet, eğitim durumu ve meslek gibi faktörlerin belirlenmesi amaçlandı.

\section{GEREÇ ve YÖNTEM}

Erciyes Üniversitesi Klinik Araştırmalar Etik Kurul onayı (Karar No: 2019/538, Tarih: 24.07.2019) alındıktan sonra 19 Ağustos 2019-17 Şubat 2020 tarihle- ri arasında hastanemizde ameliyat olacak, ameliyat öncesi muayene amacıyla anestezi polikliniğine başvuran $18-90$ yaş arası 300 hastaya anket uygulandı. "Hasta anketi" formu benzer çalışmalara ait anketler incelenerek ve anketi uyguladığımız popülasyon göz önünde bulundurularak hazırlandı ${ }^{(4,5,12,14)}$. Çalışmaya 18-90 yaş arası ameliyatı alınacak tüm erişkin hastalar rastgele olarak dahil edildi. On sekiz yaş altı, mental retarde, Türkçe bilmeyen, psikiyatrik hastalık öyküsü olan, mevcut hastalığı nedeniyle sorulara yanıt veremeyecek durumda olan, çalışmaya katılmayı reddeden ve acil ameliyat endikasyonu olan hastalar çalışma dışı bırakıldı. Çalışmaya alınan hastalara, cerrahiden en az 24 saat önce anestezi öncesi muayeneyi yapacak olan anestezi uzmanı ya da çalışma için görevlendirilen bir hemşire tarafından anket uygulandı. Hastalara çalışma hakkında gerekli bilgilerin yazılı olduğu bilgilendirilmiş onam formu okutularak onayları alındıktan sonra hastaların sessiz bir yerde herhangi bir etki altında kalmadan soruları yanıtlamaları sağlandı. Anket formuna isim yazılması gerekmediği ve verecekleri yanıtların kendilerine sunulacak hizmeti etkilemeyeceği belirtildi. Ankette bulunan tüm sorulara iyi anlayarak yanıt vermeleri istendi ve anlamadıkları herhangi bir terim ya da soru konusunda anketi yapan kişiye rahatıkla danışabilecekleri anımsatıldı. Okuma yazma bilmeyen hastaların anketleri refakatçi yakını tarafından okunarak hastanın kendi yanıtlarının işaretlenmesi sağlandı. Toplam 34 sorudan oluşan anketin (Ek 1) ilk bölümünde hastalara ait demografik veriler, ikinci bölümünde hastaların anestezi ve ameliyat uygulanmasına ilişkin bilgi ve kaygı düzeyleri, üçüncü bölümünde de anestezi uzmanı hakkında bilgi düzeyleri değerlendirildi. Tamamlanan anketler toplanarak ve yanıtlayanların gizliliğini korumak için kodlandı. Çalışmamız Helsinki Deklarasyonu'na uygun olarak yapıldı.

\section{İstatistiksel Analiz}

Anketlerden elde edilen verileri değerlendirilmesinde, tanımlayıcı istatistiklerin (ortalama, standart sapma, frekans ve yüzde değerleri) yanı sıra nitel değişkenlerin karşılaştırılmasında Pearson ki-kare testi kullanıldı. İstatistiksel değerlendirme için SPSS 22.0 (Statistical Package for the Social Sciences) yazılımı kullanılmış olup, testlerin değerlendirilmesinde $p<0.05$ değeri istatistiksel olarak anlamlı kabul edildi. 


\section{BULGULAR}

Hastanemizde çalışmanın yapıldığı 6 aylık dönemde toplam 550 hasta anestezi altında ameliyata alındı. Preoperatif muayene amacıyla polikliniğimize başvuran hastalardan 117 'si 18 yaş altı olduğu, 15'i yabancı uyruklu olduğu ve 94'ü çalışmaya katılmayı reddettiği için çalışmaya dahil edilmedi. Anket sorularının büyük çoğunluğunun eksik yanıtlanması nedeniyle de 24 anket analiz edilmeden çalışma dışı bırakıldı. Toplam 300 hastanın verileri değerlendirmeye alındı (Şekil 1). Değerlendirmeye alınan hastaların yaş ortalaması 43.48 \pm 15.85 yıldı. Hastaların \%50.33’ü kadın, \%49.67'si erkekti. Hastalara ait demografik veriler Tablo I'de verilmiştir.

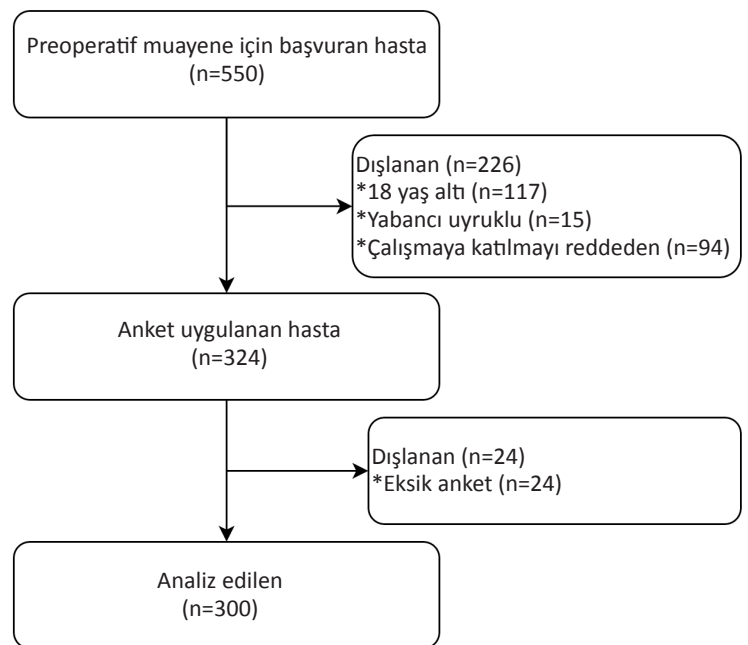

Şekil 1. Anket için Consort diyagramı

Tablo I. Hastaların demografik verileri

\begin{tabular}{llc}
\hline Parametreler & & $\mathbf{n}(\%)$ \\
\hline Yaş (YıI) & $\leq 40$ & $136(\% 45.33)$ \\
Cinsiyet & $>40$ & $164(\% 54.67)$ \\
Nerede yaşadığı & Kadın & $151(\% 50.33)$ \\
& Krkek & $149(\% 49.67)$ \\
& İlçe & $100(\% 33.33)$ \\
Mesleği & Şehir merkezi & $165(\% 55.00)$ \\
& Cevap Yok & $28(\% 9.33)$ \\
& Ev hanımı & $7(\% 2.33)$ \\
& Emekli & $120(\% 40.00)$ \\
& Kamu çalışanı & $44(\% 14.67)$ \\
& Özel Sektör & $23(\% 7.67)$ \\
& Öğrenci & $30(\% 10.00)$ \\
& İşsiz & $12(\% 4.00)$ \\
& Serbest meslek & $5(\% 1.67)$ \\
Önceki ameliyat öyküsü & Evet & $8(\% 12.67)$ \\
& Diğer & $20(\% 6.67)$ \\
Eğitim durumu & Hayır & $150(\% 50.00)$ \\
& Lise öncesi & $150(\% 50.00)$ \\
& Lise ve sonrası & $214(\% 71.33)$ \\
& Cevap Yok & $80(\% 26.67)$ \\
& & $6(\% 2.00)$ \\
\hline
\end{tabular}

Hastalara, "anestezi nedir biliyor musunuz?" sorusu soruldu. Hastaların \%46.67'si ( $n=140)$, "Anesteziyi biliyorum.", \%26.33'ü ( $n=79$ ) "Narkozu biliyorum." \%21.67'si ( $n=65)$, "Bilmiyorum." şeklinde yanıt verdi (On altı hasta bu soruyu yanıtlamadı.). "Anesteziyi kimin uyguladığı?" sorusuna hastaların \%40.67'si, "Uzman doktor." şeklinde yanıt verdi (Şekil 2) "Anestezist kimdir?" sorusuna ise hastaların \%38.67'si, "Uzman doktor." yanıtını verdi. "Anestezi polikliniğine niye geldin?" sorusuna hastaların $\% 40$ '।, "Cerrah yönlendirdi.", \%34.67'si, "Fikrim yok." şeklinde yanıt verdi. "Daha önce anestezi uzmanı ile karşılaştınız mı?" sorusuna ise \%44'ü, "Evet." dedi (Ankete verilen tüm yanıtlar Ek 2'de verilmiştir.).

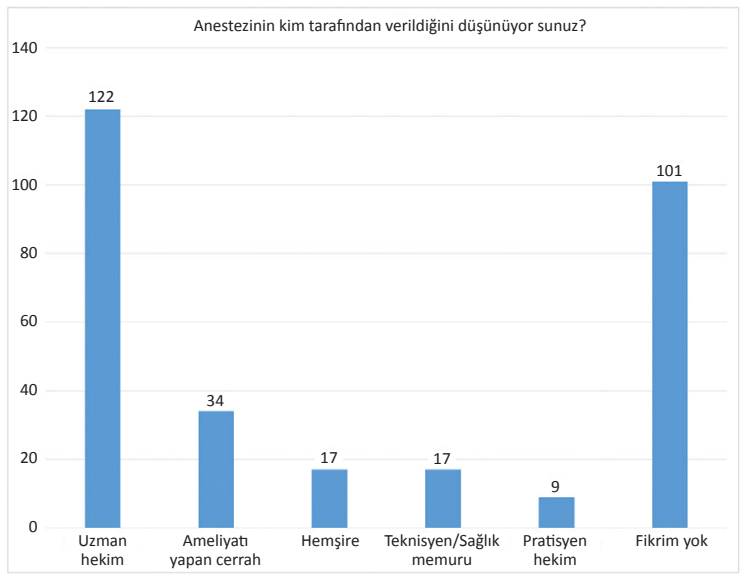

Şekil 2. Hastaların "Anestezinin kim tarafindan verildiğini düşünüyorsunuz?" sorusuna verdikleri yanıtların dağılımları

Hastalar anestezi ile ilgili endişeleri açısından değerlendirildiğinde, kadınların erkeklere göre daha endişeli olduğu belirlendi ( $p=0.009)$. Yaş, eğitim seviyesi ve önceki ameliyat öyküsü ile endişe durumu arasında anlamlı bir ilişki saptanmadı (Tablo II).

Hastalara anestezi ile ilgili korkularını daha açık dile getirmeleri istendiğinde, hastaların \%29.67'si ( $n=89$ ) "hiç korkusu olmadığını" söyledi. Hastaların korkuları arasında ilk sırada \%22.67 oranı ile ağrı duymak vardı. "Ağrı duyma" ve "anesteziden uyanamama" korkusu kadınlarda erkeklerden daha fazlaydı. "Herhangi bir korkum yok" yanıtı da eğitim düzeyi lise altı olan hastalarda ve erkeklerde daha fazlaydı. Hastaların ayrıca bölgesel anestezi ile ilgili endişeleri sorgulandı. Hastaların \%36'sı "fikrim yok", \%27'si "korkum yok" şeklinde yanıt verirken, \%17.67'si "ameliyat yerinin tam uyuşmayacağından", \%16'sı "uyanık kalıp etrafta olanların farkında olacağından", 
S. Kayaaltı, Anestezi Polikliniğine Başvuran Hastaların Anestezi ve Anestezi Uzmanı Hakkındaki Bilgi ve Kaygı Düzeylerinin Değerlendirilmesi: ilçe Devlet Hastanesi Örneği

Tablo II. Hastaların yaş, eğitim seviyesi, cinsiyet ve önceki ameliyat öyküsü durumuna göre anestezi endişe/korku düzeyleri*

\begin{tabular}{|c|c|c|c|c|c|c|c|}
\hline Parametreler & & $\begin{array}{c}\text { Hiç } \\
\text { n (\%) }\end{array}$ & $\begin{array}{l}\text { Hafif } \\
\text { n (\%) }\end{array}$ & $\begin{array}{c}\text { Orta derece } \\
n(\%)\end{array}$ & $\begin{array}{l}\text { Fazla } \\
\text { n (\%) }\end{array}$ & $\begin{array}{c}\text { Çok fazla } \\
\text { n (\%) }\end{array}$ & $\mathbf{p}$ \\
\hline \multirow[t]{2}{*}{ Yaş (Yıl) } & $\leq 40$ & $51(\% 37.50)$ & $42(\% 30.88)$ & 26 (\%19.12) & $7(\% 5.15)$ & $10(\% 7.35)$ & 0.999 \\
\hline & $>40$ & $61(\% 37.65)$ & $51(\% 31.48)$ & $30(\% 18.52)$ & $9(\% 5.56)$ & $11(\% 6.79)$ & \\
\hline \multirow[t]{2}{*}{ Cinsiyet } & Kadın & $44(\% 29.14)$ & $51(\% 33.77)$ & $32(\% 21.19)$ & $13(\% 8.61)$ & $11(\% 7.28)$ & 0.009 \\
\hline & Erkek & $68(\% 46.26)$ & $42(\% 28.57)$ & 24 (\%16.33) & $3(\% 2.04)$ & $10(\% 6.80)$ & \\
\hline \multirow[t]{2}{*}{ Eğitim seviyesi } & Lise öncesi & $64(\% 39.51)$ & $43(\% 26.54)$ & $33(\% 20.37)$ & $11(\% 6.79)$ & $11(\% 6.79)$ & 0.358 \\
\hline & Lise ve sonrası & $45(\% 34.62)$ & $48(\% 36.92)$ & $23(\% 17.69)$ & $5(\% 3.85)$ & $9(\% 6.92)$ & \\
\hline \multirow[t]{2}{*}{ Önceki ameliyat öyküsü } & Evet & $52(\% 34.90)$ & $51(\% 34.23)$ & $30(\% 20.13)$ & $6(\% 4.03)$ & $10(\% 6.71)$ & 0.596 \\
\hline & Hayır & $60(\% 40.27)$ & $42(\% 28.19)$ & $26(\% 17.45)$ & $10(\% 6.71)$ & $11(\% 7.38)$ & \\
\hline
\end{tabular}

* Anketteki 3. soruya 6 hasta, 24. soruya 2 hasta yanıt vermemiştir. Anestezi endişe/korku düzeyi istatistiği yaş, cinsiyet ve önceki ameliyat öyküsü için 298, eğitim seviyesi için 292 hasta ile yapıldı.

Tablo III. Hastaların anestezi uzmanının görev yaptığı bölümler hakkında bilgileri

\begin{tabular}{lccc}
\hline $\begin{array}{l}\text { Anestezi uzmanı } \\
\text { hastanenin hangi } \\
\text { bölümlerinde görev } \\
\text { yapar? }\end{array}$ & $\begin{array}{c}\text { Evet } \\
\mathbf{n}(\%)\end{array}$ & $\begin{array}{c}\text { Hayır } \\
\mathbf{n}(\%)\end{array}$ & $\begin{array}{c}\text { Fikrim Yok } \\
\mathbf{n}(\%)\end{array}$ \\
\hline Ameliyat odası & $232(\% 77.33)$ & $4(\% 1.33)$ & $64(\% 21.33)$ \\
Anestezi polikliniği & $159(\% 53.00)$ & $14(\% 4.67)$ & $127(\% 42.33)$ \\
$\begin{array}{l}\text { Ağrı polikliniği } \\
\text { Yoğun bakım ünitesi }\end{array}$ & $39(\% 13.00)$ & $54(\% 18.00)$ & $207(\% 69.00)$ \\
Acil servis & $52(\% 17.33)$ & $52(\% 17.33)$ & $196(\% 65.33)$ \\
$\begin{array}{l}\text { Doğum salonunda } \\
\text { Böbrek taşı kırdırma, }\end{array}$ & $89(\% 29.67)$ & $34(\% 11.33)$ & $177(\% 59.00)$ \\
Endoskopi ünitesi & $80(\% 26.67)$ & $23(\% 7.67)$ & $197(\% 65.67)$ \\
Kateter anjiyografi & $36(\% 12.00)$ & $38(\% 12.67)$ & $226(\% 75.33)$ \\
laboratuvarı, radyolojik & & & \\
görüntüleme & & & \\
\hline
\end{tabular}

\%11'i "felç olmaktan" korktuğunu belirtti.

Anestezi uzmanın hastanede görev yaptığı bölümler hastalara sorulduğunda hastaların verdiği ilk 3 yanıt sırasıyla ameliyat odası (\%77.33), anestezi polikliniği (\%53.00) ve doğum salonu (\%29.67) oldu (Tablo III).

Anestezi uzmanının sorumlulukları nelerdir sorusuna hastalar tarafından en fazla verilen yanıt \%67.67'lik oranla "ameliyattan önce hastayı uyutmak" idi; ancak "ameliyat tamamlandıktan sonra hastayı uyandırmak" \%39.67 ile daha az bilinen görevler arasındaydı (Tablo IV).

Tablo IV. Hastaların anestezi uzmanının sorumlulukları/görevleri hakkında bilgileri

\begin{tabular}{|c|c|c|c|}
\hline Anestezi uzmanının sorumlulukları/görevleri nelerdir? & $\begin{array}{l}\text { Evet } \\
\mathrm{n}(\%)\end{array}$ & $\begin{array}{l}\text { Hayır } \\
\mathrm{n}(\%)\end{array}$ & $\begin{array}{l}\text { Fikrim Yok } \\
\text { n (\%) }\end{array}$ \\
\hline Ameliyattan önce hastayı uyutmak & $203(\% 67.67)$ & $5(\% 1.67)$ & $92(\% 30.67)$ \\
\hline Ameliyat sırasında ve uyanırken hastanın ağrı duymamasını sağlamak & $134(\% 44.67)$ & $22(\% 7.33)$ & $144(\% 48.00)$ \\
\hline Ameliyat sırasında hastanın uyuma ve uyanıklığı yani bilinç durumunu takip etmek & $163(\% 54.33)$ & $7(\% 2.33)$ & $130(\% 43.33)$ \\
\hline Ameliyat sırasında hastanın kalp hızı, tansiyon gibi yaşamsal bulgularını takip etmek & $110(\% 36.67)$ & $24(\% 8.00)$ & $166(\% 55.33)$ \\
\hline Gerekirse ameliyat sırasında hastaya kan vermek & $42(\% 14.00)$ & $61(\% 20.33)$ & $197(\% 65.67)$ \\
\hline Ameliyat sırasında hastaya gerekli ilaçları vermek & $77(\% 25.67)$ & $34(\% 11.33)$ & $189(\% 63.00)$ \\
\hline Ameliyat tamamlandıktan sonra hastayı uyandırmak & $119(\% 39.67)$ & $12(\% 4.00)$ & $169(\% 56.33)$ \\
\hline Ameliyat tamamlandıktan sonra hastanın bulant-kusmasının olmamasını sağlamak & $65(\% 21.67)$ & $27(\% 9.00)$ & $208(\% 69.33)$ \\
\hline Yaşam desteği uygulayarak hastaları yaşama döndürmek & $47(\% 15.67)$ & $47(\% 15.67)$ & $206(\% 68.67)$ \\
\hline Yoğun bakımda hasta takibi ve tedavisi & $43(\% 14.33)$ & $42(\% 14.00)$ & $215(\% 71.67)$ \\
\hline Hastanın ameliyat için uygun olup olmadığını belirlemek & $101(\% 33.67)$ & $22(\% 7.33)$ & $177(\% 59.00)$ \\
\hline Hastanın ameliyat öncesi açlık süresine karar vermek & $96(\% 32.00)$ & $14(\% 4.67)$ & $190(\% 63.33)$ \\
\hline $\begin{array}{l}\text { Kanser, siyatik sinir zedelenmesi, bel fittğı sonrası gibi nedenlerden kaynaklanan sürekli ağrının } \\
\text { tedavisi için ağrı polikliniğinde çalışmak }\end{array}$ & $30(\% 10.00)$ & 37 (\%12.33) & $233(\% 77.67)$ \\
\hline
\end{tabular}

Hastalara anestezi hakkındaki bilgiyi nereden edindikleri de sorulduğunda, \%23.33'ü "anestezi hakkında bilgim yok"; \%28.67'si "Kendim ameliyat olmuştum", \%18'i "ameliyat olan bir yakınımdan" ve \%17.67'si "internet" yanıtını verdi.
Ayrıca hastalara "Eğer anestezistiniz size farklı bir anestezi yöntemi önerirse kabul eder misiniz?" ve "Kendi anestezistinizi ameliyat öncesi kendiniz seçmek ister miydiniz?" soruları da soruldu. Ilk soruya hastaların \%44'ü "kabul ederim", ikinci soruya \%49.33'ü "evet" yanıtını verdi. 


\section{TARTIŞMA}

Çalışmamız sonucunda preoperatif muayene amacıyla anestezi polikliniğine başvuran hastalarda anestezi bilgi düzeyi düşük olarak bulundu. Hastaların yalnızca \%33.33'ü anestezi bilgisini ölçmek amacıyla sorulan soruların yarısına ya da daha fazlasına doğru yanıt verdi. Anestezinin uzman bir doktor tarafından verildiğini bilenler ise hastaların yaklaşık \%40'ı idi.

Anestezi yerine eskiden narkoz kullanılmakta olup ${ }^{(15)}$, yürürlükte olan Yataklı Tedavi Kurumları Işletme Yönetmeliği'nde narkoz sözcüğü hala kullanılmaktadır. Bu nedenle çalışmamızda hastaların anesteziyi duymamış olma olasılığına karşı, "narkozu biliyor musunuz?" sorusu da soruldu. Buna rağmen "her ikisini de bilmiyorum" diyenlerin oranı oldukça yüksekti. Çalışmamız Aras ve ark.'nın ${ }^{(12)}$ yaptığı benzer bir çalışmadan 10 yıl sonra yapılmasına rağmen, anestezi ve narkozu bilmeyenlerin oranının daha yüksek bulunması il ve ilçeler arasındaki bilgi düzey farklıı̆ıını ortaya koymaktadır.

Çalışmamızda, ameliyat olacak hastaların anestezi işlemini kendilerine kimin uygulayacağını öğrenme çabalarının olmaması oldukça dikkat çekicidir. Genel popülasyonda anestezi bilgisinin değerlendirildiği çalışmalarda $(10,12,16)$ anestezi uzmanının bir doktor olduğunu bilen katııımcıların oranı \%25-40.20 arasında değişmekte iken, çalışma grubu ameliyat olacak hastalar olan çalışmalarda ${ }^{(1,4-6,14)}$ bu oran $\% 44.20$ ile \%90 olarak bulunmuştur. Çalışmalar arasındaki bu ciddi farklılık; çalışmanın yapıldığı ülke, şehir, hastane ve çalışmaya alınan katılımcıların eğitim düzeyi, yaşı gibi birçok faktörden kaynaklanabilir. Anestezi uzmanının yıllar içerisinde bilinirliğinin beklenen artışı göstermeme nedeni hastayı bilinci açıkken çok kısa süre görmesi olabilir. Çoğu merkezde anestezi uzmanı rutin postoperatif vizit yapmamaktadır. Strunin ${ }^{(17)}$ çalışmasında anestezi uzmanının ne yaptığını, nasıl bir eğitimden geçtiğini, hastalar dışında diğer sağlık çalışanlarının ve politikacıların dahi bilmediğini belirtmiştir.

Çeşitli çalışmalarda halkın ya da ameliyata gelen hastaların ameliyat odasında anestezi uzmanının rolü hakkındaki bilgisinin yetersiz olduğu, hatta ameliyat odası dışındaki görevleri hakkında daha da az bilgiye sahip olduğu gösterilmiştir ${ }^{(1,5-7,14)}$. Çalışmamız sonu- cunda da benzer sonuçlar elde edildi. Tüm anketler anestezi polikliniğinde doldurulmuş olmasına rağmen, hastaların neredeyse yarısı anestezi uzmanının anestezi polikliniğinde çalıştığı yanıtını vermedi. Bu durum bu soruların anketin son soruları olması nedeniyle hastaların sıkılarak düşünmeden hızlı yanıt vermelerinden ya da yakınlarının refakatinde işlemleri yaptırırken polikliniğinin ismine dikkat etmemelerinden kaynaklanabilir. Son yıllarda birçok merkezde yoğun bakımlar anestezi uzmanı tarafından yönetilmesine rağmen, çalışmalarda ${ }^{(1,5,7,14)}$ halkın anestezi uzmanının yoğun bakımda çalıştığını bilme oranlarının çalışmamıza benzer şekilde \%4-22.10 arasında değiştiği gösterilmiştir. Ancak, tüm bu çalışmalardan farklı olarak 2013 yılında Avusturya, Almanya ve ABD olmak üzere 3 ülkede yapılan bir çalışmada bu oranlar \%50-70 arasında bulunmuştur ${ }^{(8)}$. Ülkelerin izlediği farklı eğitim modelleri ve sağlık politikaları halkın bilinç düzeyini etkileyebilmektedir. Demir ve ark.'nın (6) çalışmasında da anestezi uzmanının çalıştığı yerler hakkında üniversite mezunları ve memurların daha bilgili olduğu bulunmuştur. Swinhoe ve Groves'ın ${ }^{(18)}$ Ingiltere'de 1994 yılında yaptığı benzer bir çalışmada, hastaların anestezi uzmanlarının yoğun bakım, ağrı, acil servis ve diğer girişimsel işlemlerde görev yaptığını bilmemesi bu görev tanımlarının anesteziye yeni eklenmesine bağlanmıştır. Hastanemiz de dahil olmak üzere birçok 2. basamak hastanede, hala ağrı polikliniği ve ameliyathane dışında anestezi hizmetinin mevcut olmaması nedeniyle halkımız bu bilgiler açısından yetersizdir.

Çalışmamızda, anestezi uzmanının görevleri sorulduğunda "ameliyattan önce hastayı uyutmak" yanıtını veren katılımcılardan bir kısmı uyandırma işini başkasının yaptığını düşündüğü bulundu. Bu durum ameliyat sonrasında hastaların tamamen uyandığında genellikle derlenme odasında hemşirelerin gözetiminde olmasından kaynaklanabilir. Ayrıca çalışmamızda, anestezi uzmanının temel sorumluluğu olan ameliyat sırasında yaşamsal bulguların takibini bilenlerin sayısı çok azdı. Lee ve ark.'nın ${ }^{(16)}$ çalışmasında da ameliyat sırasında yaşamsal bulguların takibini cerrahın hatta hemşirenin yaptığını düşünenlerin sayısı anestezi uzmanının görevi olduğunu düşünenlerden çok yüksekti ve katılımcıların çoğunluğu (\%91.60) ameliyat sırasında resüsitasyon gerekmesi durumunda bu işlemi cerrahın yaptığını düşünmekteydi. Herman'ın ${ }^{(19)} 1978$ yılında İngiltere'de yaptığı 
S. Kayaaltı, Anestezi Polikliniğine Başvuran Hastaların Anestezi ve Anestezi Uzmanı Hakkındaki Bilgi ve Kaygı Düzeylerinin Değerlendirilmesi: ilçe Devlet Hastanesi Örneği

çalışmada, hastaların \%57'si anestezi uzmanının cerrahın yönetimi altında çalıştığını belirtmiştir. Günümüzde de hastalar sıklıkla cerrahla görüştükleri için birçok işin cerrah tarafından planlandığını ve yapıldığını düşünmektedir. Halkın gözünde anestezi uzmanı imajının zayıf olması anestezi uzmanlarının işlerinden tatmin olmamalarına neden olabilmektedir ${ }^{(20)}$. Garcia-Marcinkiewicz ve ark.'nın ${ }^{(14)}$ çalışmasında, anestezi uzmanının uyutma ve uyandırma dışındaki intraoperatif görevleri hakkında (örneğin, kan kaybının izlenmesi, gerekirse ameliyat sırasında hastalara kan verilmesi) katılımcıların bilgi düzeylerinin düşük olduğu bulunmuştur. Gottschalk ve ark.'nın (8) çalışmasında da kan transfüzyonu, antibiyotik uygulaması ve postoperatif ağrı yönetimi işlemlerini anestezi uzmanlarının ya da cerrahların yaptığını düşünen hastaları sayısı benzerdir. Hastalar postoperatif dönemde daha sık gördükleri hemşire ya da cerrahları ağrı tedavisinden sorumlu olarak düşünmektedir. Bu durumu değiştirmek ve geri planda kalmamak için anestezi uzmanlarının postoperatif dönemde hastaları görmeleri zorunludur.

Çalışmamızda, kadınların erkeklere göre daha endişeli olduğu; ancak yaş, eğitim durumu ve önceki anestezi deneyiminin duyulan endişe düzeyini etkilemediği bulundu. Bu durum kadınların özellikle toplumumuzda korku ve endişelerini daha rahatlıkla dile getirebilmelerinden kaynaklanabilir. Ribeiro ve ark.'da ${ }^{(9)}$ çalışmamıza benzer şekilde kadınların daha endişeli olduğunu, önceki anestezi deneyiminin endişeyi değiştirmediğini tespit etmişlerdir. Yine, Yoldaş ve ark. ${ }^{(4)}$ kadınların tam uyuyamamaktan, gençlerin ise ağrı duymaktan ve bulantı kusmadan daha fazla endişe duyduklarını bulmuşlardır. Demir ve ark. ${ }^{(6)}$ ise endişe düzeyi ile yaşın, eğitim düzeyinin ve bilinç düzeyinin ilişkili olduğunu, yaşlı (emekli) hastaların \%43.90'ının hiçbir korkum yok yanıtını verdiğini, eğitim düzeyi düşük olanlarda da korkum yok yanıtının daha yüksek olduğunu bulmuştur. Ayrıca bilinç düzeyi artıkça endişenin arttığını da belirtmişlerdir. Bazı çalışmalarda ${ }^{(5,21)}$, çalışmamızda olduğu gibi, hastaların en çok ağrı çekmekten endişe duydukları bulunmuş iken, bazılarında ${ }^{(4,7,12,22)}$ anesteziden uyanamama ve ölüm korkusu ilk sırada yer almıştır. Özellikle 2001 ve 2009 yıllarında yapılan iki çalışmada (12,22) hastaların yarısının ölüm/uyanamama korkusu olması dikkat çekicidir. Yıllar içinde bu oranların düşmüş olması sevindiricidir. Çalışmamızda bu oranın \%15 olarak bulunması toplumda anestezinin eskisinden daha güvenli olarak görüldüğünün olumlu bir göstergesidir. Yurt dışında yapılan iki çalışmada ${ }^{(8,9)}$ çalışmamızdan farklı olarak hastaların endişeleri arasında enfeksiyonun ilk sırada olduğu bulunmuştur. Çalışmamızda, bölgesel anestezi ile ilgili en fazla duyulan endişeler Demir ve ark.'nın ${ }^{(6)}$ çalışmasına benzer şekilde ameliyat yerinin tam uyuşmayacağı ve uyanık kalıp etrafta olanların farkında olacağı idi. Anestezideki gelişmeler sayesinde yıllar içinde ameliyatların daha güvenli ve konforlu olduğu gerçeği halka medya aracılığıyla iletilmelidir. Bunun dışında gerek cerrah gerekse anestezi uzmanı tarafından preoperatif dönemde yeterli bilgilendirme ile hastaların kaygısı azaltılabilir.

Hastalar ameliyat stresi ile rutin uygulamaları sorgulamadan ve fazla önemsemeden yerine getirmekte ve anestezi polikliniğine sıklıkla cerrahın yönlendirmesi ile gelmekte ve neden geldiğini bilmemektedir. Yoldaş ve ark.'nın ${ }^{(4)}$ çalışmasında, katılımcıların yarısının eğitim seviyeleri lise ve üstü olmasına rağmen, hastaların yaklaşık \%20'si anestezi polikliniğine neden geldiğini bilmediğini belirtmiştir.

Hastanemizde hastalar elektif ameliyat öncesi anestezi uzmanı tarafından bilgilendirilerek anestezi onam formu imzalatılmaktadır. Buna rağmen çalışmamızda daha önce hiç anestezi uzmanı ile karşılaşmadığını dile getiren hastaların \%37.20'si daha önce ameliyat olmuş hastalardı. Hariharan ve ark.'nın (1) çalışmasında da hastaların yaklaşık \%6'sı daha önce anestezi almasına rağmen, anestezi uzmanı ile görüşmediklerini belirtmişlerdir. Çalışmamızın sonucuna göre, anestezi uzmanı olarak preoperatif muayene için gelen hastalara kendimizi daha net bir şekilde tanıtmamız gerektiği açıktır. Ayrıca çalışmalar göstermektedir ki; hastalar anestezi seçenekleri, anestezinin komplikasyonları, ağrı kontrolü ve kullanılan ilaçlar da dahil olmak üzere kapsamlı bilgiyi bizzat anestezi doktorundan almak istemektedir $(4,14)$. Preoperatif vizit sırasında ve ameliyat öncesinde ameliyathanede hastalara kendimizi tanıtmamız, kendilerine hangi işlemleri uygulayacağımızı ve ameliyat süresince ya da sonrasında beklenen ya da beklenmeyen durumlarda en uygun şekilde müdahale yapılacağını ayrıntılı anlatmamız gerekmektedir. Bu hem anestezi bilgisinin artması hem de ameliyat ile ilgili endişelerin azalması açısından yararlı olacaktır. 
Hariharan ve ark.'nın (1) çalışmasında, hastalara anestezi uzmanının tutumları hakkında sorular yöneltilmiş, hastaların \%70'i anestezi uzmanının kendini tanıttığını, sıcak yaklaşımda bulunduğunu belirtmiş; ancak olası komplikasyonlar, ilaç yan etkileri ya da hastaların kendi sorularına yanıt verme konusunda yalnızca yaklaşık \%40'ının tatmin olduğu bulunmuştur. Hastaları bilgilendirirken beklentilerini karşılayacak, ancak endişelerini artırmayacak kadar detaylı bilgiler verilmelidir. Yaş, cinsiyet ve eğitim düzeyi gibi farklılıklar nedeniyle nelerden bahsedileceği her hasta için değişiklik göstermelidir. Ayrıca toplumun doğru şekilde bilgilendirilmesi için de televizyon, gazete, dergi gibi medya ve sosyal medya, tanıtıc broşürler vb. araçlar yoluyla sık sık eğitimler verilmelidir. Lee ve ark'nın ${ }^{(16)}$ çalışmasında, katılımcılara anestezi konusunda nasıl bilgi almak istedikleri sorulmuş, halkın ilk tercihi televizyon ile bilgilendirilmek olmuştur. Televizyon sayesinde hastalar dışında halkın da bilgi düzeyini artırmak olası olacaktır. Televizyon dışında özellikle bilgilendirme broşürleri hem hasta hem de yakınları için tekrar tekrar bakabilmesi açısından avantajlı olacaktır.

Çalışma popülasyonumuz yalnızca ameliyat öncesi muayeneye gelen hastalardı. Bu hastaların ameliyatları ve anestezi hakkında yakınlarından ya da medyadan bilgi almaları olasıdır. Bu nedenle sonuçlarımız genel popülasyonu tam olarak yansıtmayabilir.

\section{SONUÇ}

Bu çalışmanın sonuçlarına göre, hastalar ameliyat ve anestezi konusunda birçok endişe duyduğunu belirtmesine rağmen, bu süreçte tıbbi bakımlarından kimin sorumlu olduğu konusunda yeterli bilgiye sahip değildi. Ayrıca anestezi uygulamaları hakkında da hastaların büyük kısmının yeterli bilgisi yoktu. Bu konuda okullarda ya da medya aracılığıyla halkın bilgilendirilmesi ya da hastanelerde dağıtılacak broşür ya da sunulacak video eğitimleriyle ve anestezi uzmanının perioperatif süreçte kendi çabalarıyla anestezi hakkında hastaların farkındalığının artırılması gerektiğini düşünüyoruz. Hastalar kendilerini yıllarını bu işe veren deneyimli bir uzmanın eline bıraktıklarını düşünürse olasılıkla anestezi işlemi hakkında çok daha az kaygı duyacak ve anestezi korkusu nedeniyle kaçındıkları, erteledikleri elektif ameliyat kararlarını daha rahat verecektir. Bu ve benzeri çalış- maların her 5-10 yılda bir yapılmasının anestezi farkındalığının belirlenmesi açısından yararlı olacağını düşünüyoruz.

Etik Kurul Onayı: Erciyes Üniversitesi Klinik Araştırmalar Etik Kurulu onayı alınmıştır (24.07.2019 tarih ve 2019/538 sayı)

Çıkar Çatışması: Yoktur

Finansal Destek: Yoktur

Hasta Onamı: Alınmıştır

Ethics Committee Approval: Erciyes University Clinical Research Ethics Committee approval was received (date 24.07.2019 and number 2019/538)

Conflict of Interest: None

Funding: None

Informed Consent: The patients' consent were obnained

\section{KAYNAKLAR}

1. Hariharan S, Merritt-Charles L, Chen D. Patient perception of the role of anesthesiologists: a perspective from the Caribbean. J Clin Anesth. 2006;18:504-9. https://doi.org/10.1016/j.jclinane.2006.03.004

2. Şekerci S, Akpek E, Göktuğ A, et al. Hasta ve yakınları ile toplumun farklı kesimlerinin anestezi ve uygulamaları konusundaki bilgi ve davranışları. JARSS. 2001;9:4851.

3. Ceyhan $A$, Basar $H$, İnan $N$, Yağmurdur $H$, Çetinbaş $R$, Parpucu M. Türk toplumu anestezi hakkında neler biliyor, neler bilmiyor. Sendrom. 2000;12:75-9.

4. Yoldaş TK, Yoldaş M, Karagöz S, et al. Preanestezik değerlendirmede hastaların anestezi uygulamalarına ilişkin bilgi, deneyim ve kaygıları ile ilgili anket çalışması. Ege Tıp Derg. 2016;55:109-16. https://doi.org/10.19161/etd.344206

5. Türkyılmaz HEU, Eryılmaz NC, Güzey NA, Gedikli A. Hastaların anestezi hakkında bilgi düzeylerinin saptanması ve anestezi öncesi korkularının belirlenmesi. Çağdaş Tıp Derg. 2018;8:350-5. https://doi.org/10.16899/gopctd.435950

6. Demir A, Turan S, Balaban F, Karadeniz Ü, Erdemli Ö. Anestezi uygulamaları ile ilgili olarak preanestezik değerlendirme sırasında hastalarda yapılan anket çalışması. Türk Anest Der Dergisi. 2009;37:225-33.

7. Sagün A, Birbiçer H, Yapici G. Patients', who applied to the anesthesia clinic, perceptions and knowledge about anesthesia in Türkiye. Saudi J Anaesth. 2013;7:170-4.

https://doi.org/10.4103/1658-354X.114076

8. Gottschalk A, Seelen S, Tivey S, Gottschalk A, Rich G. What do patients know about anesthesiologists? Results of a comparative survey in an US, Australian, and German university hospital. J Clin Anesth. 2013;25:85-91.

https://doi.org/10.1016/j.jclinane.2012.06.017

9. Ribeiro CS, Mourão JIdB. Anesthesiologist: the patient's 
perception. Braz J Anesthesiol. 2015;65:497-503. https://doi.org/10.1016/j.bjan.2014.05.014

10. Singh T, Sharma S, Banerjee B, Garg S. Knowledge regarding anesthesiologist and anesthesiology among patients and attendants attending a rural hospital of New Delhi. J Edu Health Promot. 2018;7:12. https://doi.org/10.4103/jehp.jehp_52_17

11. Uma BR, Hanji AS. Anaesthesia and anaesthesiologists: how famous are we among the general population?-a survey. J Clin Diagn Res. 2013;7:2898-900. https://doi.org/10.7860/JCDR/2013/7084.3788

12. Aras D, Çil C, Akçaoğlu AC, Erbay RH, Zencir M. Denizli ili Yenişehir Sağıı Ocağı bölgesinde halkın anesteziyoloji uygulamalarına ilişkin bilgi, tutum ve önceki anestezi deneyimleri. Pamukkale Tıp Derg. 2008:76-82.

13. Kagan I, Bar-Tal Y. The effect of preoperative uncertainty and anxiety on short-term recovery after elective arthroplasty. J Clin Nurs. 2008;17:576-83. https://doi.org/10.1111/j.1365-2702.2007.01968.x

14. Garcia-Marcinkiewicz AG, Long TR, Danielson DR, Rose $\mathrm{SH}$. Health literacy and anesthesia: patients' knowledge of anesthesiologist roles and information desired in the preoperative visit. J Clin Anesth. 2014;26:375-82. https://doi.org/10.1016/j.jclinane.2014.01.013

15. Türe H, Özel MU, Gümüş H, Çoraklı D. Türkiye'de anesteziyoloji ve reanimasyon biliminin tarihsel gelişimi. Bilgin H, editor. Bursa: TARD Yayınları 2016.

16. Lee JJ, Lee NH, Park CM, et al. Public awareness about the specialty of anesthesiology and the role of anesthesiologists: a national survey. Korean J Anesthesiol. 2014;66:12-7. https://doi.org/10.4097/kjae.2014.66.1.12

17. Strunin L. Anaesthesia, what's in a name?-time for change. Anaesthesia. 2000;55:941-2. https://doi.org/10.1046/j.1365-2044.2000.01784.x

18. Swinhoe CF, Groves ER. Patients' knowledge of anaesthetic practice and the role of anaesthetists. Anaesthesia. 1994;49:165-6. https://doi.org/10.1111/j.1365-2044.1994.tb03380.x

19. Herman CR. An appraisal of the anaesthetist-patient relationship. Anaesthesia. 1978;33:45-8. https://doi.org/10.1111/j.1365-2044.1978.tb08278.x

20. Irwin MG, Soon NTC, Fung SKY. A profile of anaesthesia trainees in Hong Kong. Hong Kong Med J. 2001;7:22735.

21. Mavridou P, Dimitriou V, Manataki A, Arnaoutoglou E, Papadopoulos G. Patient's anxiety and fear of anesthesia: effect of gender, age, education, and previous experience of anesthesia. A survey of 400 patients. J Anesth. 2013;27:104-8 https://doi.org/10.1007/s00540-012-1460-0

22. Uysal Aì, Güner Ö, İnal FY, Yılmaz Y. Tokat Devlet Hastanesinde genel ve rejyonal anestezi uygulanan hastaların anestezi bilgi düzeyini ve memnuniyetini değerlendirme anketi. Çağdaş Tıp Derg. 2013;3:82-7. 
Ek 1. Anket Soruları

HASTA ANKETi

Anestezi ve anestezi uzmanlarının rolünü hakkında hastalarımızın daha iyi bilgi sahibi olmalarına nasıl yardımcı olabileceğimizi öğrenmek istiyoruz. Aşağıdaki soruları yanıtlayarak bize yardımcı olursanız memnun oluruz.

\section{HAKKINIZDA}

1. Yaş :

2. Cinsiyet: $\square$ Kadın $\square$ Erkek

3. Eğitim durumu: $\square$ Okur-Yazar değil $\square$ Okur-Yazar $\square$ Lise $\quad \square$ Üniversite (2 Yıllık) $\square$ İlkokul $\square$ Ortaokul

4. Mesleği :

$\square$ Ev hanımı $\square$ Emekli $\square$ Kamu çalışanı

$\square$ Üniversite (4 Yıllık ve üzeri) $\square$ Öğrenci

5. Nerede yaşıyorsunuz? $\square$ Köy $\square$ Işsiz $\square$ Serbest meslek $\square$ Diğer

6. Herhangi bir ilaca alerjiniz var mı? $\square$ Evet $\square$ Hayır

7. Anestezi polikliniğine neden geldiniz?

$\square$ Anestezi altında ameliyat olmam uygun mu öğrenmek için

$\square$ Kullandığım ilaçları söylemek için

$\square$ Daha önce olduğum ameliyatlar / bunlar sırasındaki narkoz bilgileri hakkında bilgi vermek için

8. Daha önce kaç kere ameliyat oldunuz?

$\square$ Şehir merkezi

$\square$ Alerji durumumu ve ilaç alerjilerimi söylemek için $\square$ Ek hastalıklarım hakkında bilgi vermek için $\square$ Cerrah benim buraya gelmemi söylediği için $\square$ Fikrim yok

\section{ANESTEZI/AMELIYAT HAKKINDA}

9. Anestezi nedir?

$\square$ Biliyorum $\square$ Anesteziyi bilmiyorum, narkozu biliyorum

10. Anestezinin kim tarafından verildiğini düşünüyorsunuz?

$\square$ Uzman hekim $\quad \square$ Pratisyen hekim

$\square$ Teknisyen $\square$ Sağlık memuru

11. Anestezi uygulaması nasıl yapııır?

$\square$ Gaz koklatılarak $\square$ Damardan ilaç verilerek

$\square$ Her üçü de uygulanabilir

12. Ameliyat gerektiğinde anestezi uygulanmalı mıdır?
$\square$ Evet
$\square$ Hayır
$\square$ Fikrim yok

13. Anestezi sizce tüm hastalara aynı yöntemle mi uygulanır?
$\square$ Evet
$\square$ Hayır

14. Aşağıdaki hangi anestezi yöntemlerini biliyorsunuz?

$\square$ Genel anestezi $\square$ Lokal anestezi

15. Anestezi nerede alacağınızı biliyor musunuz?
$\square$ Hasta odası
$\square$ Ameliyathane bekleme salonu

$\square$ Ameliyatı yapan cerrah

$\square$ Bilmiyorum

16. Anestezi

ra ne kadar sürede uyuyacağınızı düşünüyorsunuz?

$\square$ Sadece ameliyat bölgesini uyuşturarak

$\square$ Fikrim yok
$\square 30$ saniye
$\square 1$ dakika
$\square 5$ dakika

Hemşire

17. Ameliyat bitiminde sizce nerede uyanacaksınız?

$\square$ Ameliyathane odasında $\square$ Ameliyat sonrası derlenme odasında $\square$ Hasta odasında

$\square$ Yoğun bakım ünitesinde $\square$ Fikrim yok

18. Ameliyat için uyutulduktan sonra ameliyat esnasında olanları hatırlayacağınızı düşünüyor musunuz?
$\square$ Hayır
$\square$ Kısmen hatırlayacağım
$\square$ Her şeyi hatırlayacağım $\square$ Fikrim yok

19. Diyabet, astım, hipertansiyon, karaciğer disfonksiyonu, kalp rahatsızıı̆ı, epilepsi, yaşlı olmak, sigara kullanmak ve alkolik olmak anestezi riskini arttırır mı?
$\square$ Evet
$\square$ Hayır
$\square$ Fikrim yok

20. Yaş ve kilo verilen anestezi için verilen ilaç miktarını etkiler mi?
$\square$ Evet
$\square$ Hayır
$\square$ Fikrim yok

21. Anesteziden önce;

$\square$ Sadece katı yiyecekler yenmemelidir

$\square$ Hem katı hem sıvı besinler yenmemelidir

$\square$ Hiçbir şeyin kesilmesine gerek yoktur

22. Operasyon öncesi aç kalma süresi kaç saattir?

$\square 2$ saat $\square 6$ saat $\square 12$ saat $\square 24$ saat $\square$ Fikrim Yok

23. Sizce ameliyattan önce aç kalmak neden gereklidir?

$\checkmark$ Uyurken, yiyecekler akciğerlere gidebilir kaçabilir

$\square$ Ameliyat sırasında cerrahi zor olabilir

24. Anestezi alma konusunda endişeli/korkuyor musunuz?

$\begin{array}{ll}\square \text { Hiç endişem/korkum yok } & \square \text { Hafif endişem/korkum var } \square \text { Orta derecede endişem/korkum var } \\ \square \text { Fazla endişeliyim/korkuluyum } & \square \text { Çok fazla endişem/korkum var }\end{array}$ 
S. Kayaaltı, Anestezi Polikliniğine Başvuran Hastaların Anestezi ve Anestezi Uzmanı Hakkındaki Bilgi ve Kaygı Düzeylerinin Değerlendirilmesi: illçe Devlet Hastanesi Örneği

25. Anestezi işlemi ile ilgili endişeleriniz/korkularınız nelerdir? Birden fazla şık seçebilirsiniz

$\square$ Herhangi bir endişem/korkum yok

$\square$ Ağrı duyacağım

$\square$ Ameliyatta tam uyuyamayacağım

$\square$ Anesteziden uyanamayacağım

$\square$ Bulantım kusmam olacak

$\square$ Operasyon sonrasında yoğun bakımda kalacağım

๑ Çevreyi tanıyamayacağım

$\square$ Boğazım ağrıyacak

$\square$ Her hangi bir aksilik

$\square$ Anestezistin deneyimsiz olması

$\square$ Bilincimi kaybedip istemediğim şeyler söyleyeceğim/yapacağım

26. Bölgesel anestezi (belden uyuşturma) işlemi ile ilgili endişeleriniz/korkularınız nelerdir? Birden fazla şık seçebilirsiniz

$\square$ Herhangi bir korkum yok

$\square$ Fikrim yok

$\square$ Ameliyat yerinin yeterince uyuşmayacağını düşünüyorum düşünüyorum

$\square$ Uyanık kalıp etrafta olanların farkında olacağımdan endişeliyim

27. Anestezi hakkında bilgileri nereden edindiniz? Birden fazla şık seçebilirsiniz

$\square$ Anestezi hakkında bilgim yok $\square$ Kendim ameliyat olmuştum

$\square$ İnternet

$\square$ Televizyon

$\square$ Gazete

$\square$ Ameliyat olan bir yakınımdan

\section{ANESTEZIST HAKKINDA}

28. Daha önce anestezi uzmanı ile karşılaştınız mı?

$\square$ Evet

$\square$ Hayır

29. Anestezist kimdir?

$\square$ Cerrahın asistanı

$\square$ Anestezide özel eğitim almış bir hemşire

$\square$ Fikrim yok

30. Her operasyonda anestezist olmalı mıdır?

$\square$ Evet $\square$ Hayır

$\square$ Felç olabileceğimi

$\square$ Diğer

31. Eğer anestezistiniz size farklı bir ane
$\square$ Kabul ederim
$\square$ Kabul etmem

32. Kendi anestezistinizi ameliyat öncesi kendiniz seçmek ister miydiniz?

$\square$ Evet

$\square$ Hayır

33. Anestezi uzmanı hastanenin hangi bölümlerinde görev yapar?

\begin{tabular}{|l|l|l|l|}
\hline Ameliyathane & $\square$ Evet & $\square$ Hayır & $\square$ Fikrim yok \\
\hline Anestezi Polikliniği & $\square$ Evet & $\square$ Hayır & $\square$ Fikrim yok \\
\hline Ağı Polikliniği & $\square$ Evet & $\square$ Hayır & $\square$ Fikrim yok \\
\hline Yoğun Bakım Ünitesi & $\square$ Evet & $\square$ Hayır & $\square$ Fikrim yok \\
\hline Acil Servis & $\square$ Evet & $\square$ Hayır & $\square$ Fikrim yok \\
\hline Doğum Salonunda & $\square$ Evet & $\square$ Hayır & $\square$ Fikrim yok \\
\hline $\begin{array}{l}\text { Böbrek taşı kırdırma (ESWL),Endoskopi Ünitesi(kolonoskopi, ERCP, hortumla mideye, } \\
\text { bağırsağa bakma) }\end{array}$ & $\square$ Evet & $\square$ Hayır & $\square$ Fikrim yok \\
\hline Kateter anjio laboratuvarı, Radyolojik görüntüleme (tomografi çekimi, opak alerjisi) & $\square$ Evet & $\square$ Hayır & $\square$ Fikrim yok \\
\hline
\end{tabular}

34. Anestezi uzmanının sorumlulukları/görevleri nelerdir?

\begin{tabular}{|l|l|l|l|}
\hline Ameliyattan önce hastayı uyutmak & $\square$ Evet & $\square$ Hayır & $\square$ Fikrim yok \\
\hline Ameliyat esnasında ve uyanırken hastanın ağıı duymamasını sağlamak & $\square$ Evet & $\square$ Hayır & $\square$ Fikrim yok \\
\hline Ameliyat esnasında hastanın uyuma ve uyanıklı̆ı yani bilinç durumunu takip etmek & $\square$ Evet & $\square$ Hayır & $\square$ Fikrim yok \\
\hline Ameliyat esnasında hastanın kalp hızı, tansiyon gibi yaşamsal bulgularını takip etmek & $\square$ Evet & $\square$ Hayır & $\square$ Fikrim yok \\
\hline Gerekirse ameliyat sırasında hastaya kan vermek & $\square$ Evet & $\square$ Hayır & $\square$ Fikrim yok \\
\hline Ameliyat esnasında hastaya gerekli ilaçları vermek & $\square$ Evet & $\square$ Hayır & $\square$ Fikrim yok \\
\hline Ameliyat tamamlandıktan sonra hastayı uyandırmak & $\square$ Evet & $\square$ Hayır & $\square$ Fikrim yok \\
\hline Ameliyat tamamlandıktan sonra hastanın bulantı kusmasının olmamasını sağlamak & $\square$ Evet & $\square$ Hayır & $\square$ Fikrim yok \\
\hline Yaşam desteği uygulayarak hastaları hayata döndürmek & $\square$ Evet & $\square$ Hayır & $\square$ Fikrim yok \\
\hline Yoğun bakımda hasta takibi ve tedavisi & $\square$ Evet & $\square$ Hayır & $\square$ Fikrim yok \\
\hline Hastanın ameliyat için uygun olup olmadığını belirlemek & $\square$ Evet & $\square$ Hayır & $\square$ Fikrim yok \\
\hline Hastanın operasyon öncesi açlık süresine karar vermek & $\square$ Evet & $\square$ Hayır & $\square$ Fikrim yok \\
\hline $\begin{array}{l}\text { Kanser, siyatik sinir zedelenmesi, bel fıtığı sonrası gibi sebeplerden kaynaklanan sürekli } \\
\text { ağrının tedavisi için ağrı polikliniğinde çalışmak }\end{array}$ & $\square$ Evet & $\square$ Hayır & $\square$ Fikrim yok \\
\hline
\end{tabular}


Ek 2. Anket sorularına verilerin cevapların dağııımı

\begin{tabular}{|c|c|c|}
\hline Anket Soruları & Verilen Cevap & $\mathrm{n}(\%)$ \\
\hline \multirow{7}{*}{ 7. Anestezi Polikliniğine neden geldiniz? } & Cerrah benim buraya gelmemi söylediği için & $120(\% 40.00)$ \\
\hline & Ameliyat olmam uygun mu öğrenmek için & $64(\% 21.33)$ \\
\hline & Daha önce olduğum ameliyatlar bilgilerini vermeye & $14(\% 4.67)$ \\
\hline & Alerji durumum ve ilaç alerjilerimi söylemek için & $4(\% 1.33)$ \\
\hline & Ek hastalıklarım hakkında bilgi vermek için & $4(\% 1.33)$ \\
\hline & Kullandığım ilaçları söylemek için & $2(\% 0.67)$ \\
\hline & Fikrim yok & $104(\% 34.67)$ \\
\hline \multirow{2}{*}{ 8. Daha önce ameliyat oldunuz mu? } & Evet & $150(\% 50.00)$ \\
\hline & Hayır & $150(\% 50.00)$ \\
\hline \multirow{4}{*}{ 9. Anestezi nedir? } & Biliyorum & $140(\% 46.67)$ \\
\hline & Anesteziyi bilmiyorum, narkozu biliyorum & $79(\% 26.33)$ \\
\hline & Bilmiyorum & $65(\% 21.67)$ \\
\hline & Cevap yok & $16(\% 5.33)$ \\
\hline \multirow{6}{*}{$\begin{array}{l}\text { 10. Anestezinin kimin tarafından verildiğini } \\
\text { düşünüyorsunuz }\end{array}$} & Uzman hekim & $122(\% 40.67)$ \\
\hline & Ameliyatı yapan cerrah & $34(\% 11.33)$ \\
\hline & Hemşire & $17(\% 5.67)$ \\
\hline & Teknisyen/Sağlık memuru & $17(\% 5.67)$ \\
\hline & Pratisyen hekim & $9(\% 3.00)$ \\
\hline & Fikrim yok & $101(\% 33.67)$ \\
\hline \multirow{5}{*}{ 11. Anestezi uygulaması nasıl yapılır? } & Damardan ilaç verilerek & $83(\% 27.67)$ \\
\hline & Her üçü de uygulanabilir & $51(\% 17)$ \\
\hline & Sadece ameliyat bölgesini uyuşturarak & $25(\% 8.33)$ \\
\hline & Gaz koklatılarak & $19(6.33)$ \\
\hline & Fikrim yok & $125(\% 41.67)$ \\
\hline \multirow{3}{*}{$\begin{array}{l}\text { 12. Ameliyat gerektiğinde anestezi uygulanmalı } \\
\text { mıdır? }\end{array}$} & Evet & $201(\% 67.00)$ \\
\hline & Hayır & $9(\% 3.00)$ \\
\hline & Fikrim yok & $90(\% 30.00)$ \\
\hline \multirow{3}{*}{$\begin{array}{l}\text { 13. Anestezi sizce tüm hastalara ayni yöntemle } \\
\text { mi uygulanır? }\end{array}$} & Hayır & $132(\% 44.00)$ \\
\hline & Evet & $32(\% 10.67)$ \\
\hline & Fikrim yok & $136(\% 45.33)$ \\
\hline \multirow{5}{*}{$\begin{array}{l}\text { 14. Aşağıdaki hangi anestezi yöntemlerini } \\
\text { biliyorsunuz }\end{array}$} & Hepsi & $79(\% 26.33)$ \\
\hline & Genel anestezi & $45(\% 15.00)$ \\
\hline & Lokal anestezi & $23(\% 7.67)$ \\
\hline & Bölgesel anestezi & $19(\% 6.33)$ \\
\hline & Hiçbiri & $122(\% 40.67)$ \\
\hline \multirow{4}{*}{ 15. Anestezi nerede alacağınızı biliyor musunuz? } & Ameliyathane odasında & $173(\% 57.67)$ \\
\hline & Ameliyathane bekleme salonu & $33(\% 11.00)$ \\
\hline & Hasta odası & $7(\% 2.33)$ \\
\hline & Fikrim yok & $87(\% 29.00)$ \\
\hline \multirow{4}{*}{$\begin{array}{l}\text { 16. Anestezi verildikten sonra ne kadar sürede } \\
\text { uyuyacağınızı düşünüyorsunuz? }\end{array}$} & 30 saniye & 47 (\%15.67) \\
\hline & 1 dakika & $36(\% 12.00)$ \\
\hline & 5 dakika & $35(\% 11.67)$ \\
\hline & Fikrim yok & $182(\% 60.67)$ \\
\hline \multirow{5}{*}{$\begin{array}{l}\text { 17. Ameliyat bitiminde sizce nerede } \\
\text { uyanacaksınız }\end{array}$} & Hasta odasında & $125(\% 41.67)$ \\
\hline & Ameliyat sonrası derlenme odasında & 55 (\%18.33) \\
\hline & Ameliyathane odasında & $38(\% 12.67)$ \\
\hline & Yoğun bakım ünitesinde & $7(\% 2.33)$ \\
\hline & Fikrim yok & $75(\% 25.00)$ \\
\hline \multirow{4}{*}{$\begin{array}{l}\text { 18. Ameliyat için uyutulduktan sonra ameliyat } \\
\text { esnasında olanları hatırlayacağınızı düşünüyor } \\
\text { musunuz? }\end{array}$} & Hayır & $134(\% 44.67)$ \\
\hline & Kısmen hatırlayacağım & $48(\% 16.00)$ \\
\hline & Her şeyi hatırlayacağım & $12(\% 4.00)$ \\
\hline & Fikrim yok & $106(\% 35.33)$ \\
\hline \multirow{3}{*}{$\begin{array}{l}\text { 19. Diyabet, astım, hipertansiyon, karaciğer } \\
\text { disfonksiyonu, kalp rahatsızı̆̆ı, epilepsi, yaşlı } \\
\text { olmak, sigara kullanmak ve alkolik olmak } \\
\text { anestezi riskini arttırır mı? }\end{array}$} & Evet & $127(\% 42.33)$ \\
\hline & Hayır & $13(\% 4.33)$ \\
\hline & Fikrim yok & $160(\% 53.33)$ \\
\hline & Evet & $104(\% 34.67)$ \\
\hline $\begin{array}{l}\text { 20. Yaş ve kılo verılen anestezı I ı̧ın verılen ılaç } \\
\text { miktarını etkiler mi? }\end{array}$ & Hayır & $8(\% 2.67)$ \\
\hline & Fikrim yok & $188(\% 62.67)$ \\
\hline & Hem kati hem sıvı besinler yenmemelidir & $128(\% 42.67)$ \\
\hline & Az az yiyecek yenebilir & $15(\% 5.00)$ \\
\hline 21 Anecteziden önce. & Sadece sıvı içecekler içilmemelidir & $13(\% 4.33)$ \\
\hline 21. Anestezıden once; & Hiçbir şeyin kesilmesine gerek yoktur & $12(\% 4.00)$ \\
\hline & Sadece kati yiyecekler yenmemelidir & $4(\% 1.33)$ \\
\hline & Fikrim yok & $130(\% 43.33)$ \\
\hline 22. Operasyon öncesi aç kalma süresi kaç saattir & 12 saat & $118(\% 39.33)$ \\
\hline & 6 saat & $43(\% 14.33)$ \\
\hline & 24 saat & $15(\% 5.00)$ \\
\hline & 2 saat & $7(\% 2.33)$ \\
\hline & Fikrim yok & $117(\% 39.00)$ \\
\hline
\end{tabular}


S. Kayaaltı, Anestezi Polikliniğine Başvuran Hastaların Anestezi ve Anestezi Uzmanı Hakkındaki Bilgi ve Kaygı Düzeylerinin Değerlendirilmesi: İlçe Devlet Hastanesi Örneğ

\begin{tabular}{|c|c|c|}
\hline \multirow{4}{*}{$\begin{array}{l}\text { 23. Sizce ameliyattan önce aç kalmak neden } \\
\text { gereklidir? }\end{array}$} & Ameliyat sonrası bulantı kusma olabilir & $76(\% 25.33)$ \\
\hline & Ameliyat sırasında cerrahi zor olabilir & $42(\% 14.00)$ \\
\hline & Uyurken yiyecekler akciğerlere gidebilir kaçabilir & $39(\% 13.00)$ \\
\hline & Fikrim yok & $150(\% 50.00)$ \\
\hline \multirow{6}{*}{$\begin{array}{l}\text { 24. Anestezi alma konusunda endişeli/korkuyor } \\
\text { musunuz? }\end{array}$} & Hiç endişem/korkum yok & $112(\% 37.33)$ \\
\hline & Hafif endişem/korkum var & $93(\% 31.00)$ \\
\hline & Orta derecede endişem/korkum var & $56(\% 18.67)$ \\
\hline & Çok fazla endişem/korkum var & $21(\% 7.00)$ \\
\hline & Fazla endişeliyim/korkuluyum & $16(\% 5.33)$ \\
\hline & Cevap yok & $2(\% 0.67)$ \\
\hline \multirow{11}{*}{$\begin{array}{l}\text { 25. Anestezi işlemi ile ilgili } \\
\text { endişeleriniz/korkularınız nelerdir? }\end{array}$} & Herhangi bir endişem korkum yok & 89 (\%29.67) \\
\hline & Ağrı duyacağım & $68(\% 22.67)$ \\
\hline & Her hangi bir aksilik & $63(\% 21.00)$ \\
\hline & Anesteziden uyanamayacağım & $45(\% 15.00)$ \\
\hline & Bilincimi kaybedip istemediğim şeyler söyleyeceğim yapacağım & $38(\% 12.67)$ \\
\hline & Anestezistin deneyimsiz olması & $31(\% 10.33)$ \\
\hline & Ameliyatta tam uyuyamayacağım & $28(\% 9.33)$ \\
\hline & Bulantım kusmam olacak & $27(\% 9.00)$ \\
\hline & Çevreyi tanıyamayacağım & $15(\% 5.00)$ \\
\hline & Boğazım ağrıyacak & $13(\% 4.33)$ \\
\hline & Operasyon sonrasında yoğun bakımda kalacağım & $8(\% 2.67)$ \\
\hline \multirow{6}{*}{$\begin{array}{l}\text { 26. Bölgesel anestezi (belden uyuşturma) işlemi } \\
\text { ile ilgili endişeleriniz/korkularınız nelerdir? }\end{array}$} & Herhangi bir korkum yok & $82(\% 27.33)$ \\
\hline & Ameliyat yerinin yeterince uyuşmayacağını düşünüyorum & $53(\% 17.67)$ \\
\hline & Uyanık kalıp farkında olacağımdan endişeliyim & $48(\% 16.00)$ \\
\hline & Felç olabileceğimi düşünüyorum & $33(\% 11.00)$ \\
\hline & Diğer & $11(\% 3.67)$ \\
\hline & Fikrim yok & $108(\% 36.00)$ \\
\hline \multirow{7}{*}{$\begin{array}{l}\text { 27. Anestezi hakkında bilgileri nereden } \\
\text { edindiniz? }\end{array}$} & Kendim ameliyat olmuştum & $86(\% 28.67)$ \\
\hline & Anestezi hakkında bilgim yok & $70(\% 23.33)$ \\
\hline & Ameliyat olan bir yakınımdan & $54(\% 18.00)$ \\
\hline & İnternet & $53(\% 17.67)$ \\
\hline & Televizyon & $20(\% 6.67)$ \\
\hline & Gazete & $1(\% 0.33)$ \\
\hline & Diğer & $27(\% 9.00)$ \\
\hline \multirow{3}{*}{$\begin{array}{l}\text { 28. Daha önce anestezi uzmanı ile karşılaştınız } \\
\text { mı? }\end{array}$} & Hayır & $164(\% 54.67)$ \\
\hline & Evet & $132(\% 44.00)$ \\
\hline & Cevap yok & $4(\% 1.33)$ \\
\hline \multirow{5}{*}{ 29. Anestezist kimdir? } & Anestezi konusunda uzmanlaşmış bir doktor & $116(\% 38.67)$ \\
\hline & Doktor veya hemşire olmayan bir teknik uzman & $33(\% 11.00)$ \\
\hline & Anestezide özel eğitim almış bir hemşire & $28(\% 9.33)$ \\
\hline & Cerrahın asistanı & $15(\% 5.00)$ \\
\hline & Fikrim yok & $108(\% 36.00)$ \\
\hline \multirow{3}{*}{ 30. Her operasyonda anestezist olmalı mıdır? } & Evet & $117(\% 39.00)$ \\
\hline & Hayır & $54(\% 18.00)$ \\
\hline & Fikrim yok & $129(\% 43.00)$ \\
\hline \multirow{3}{*}{$\begin{array}{l}\text { 31. Anestezistiniz farklı yöntemi önerirse kabul } \\
\text { eder misiniz? }\end{array}$} & Kabul etmem & $142(\% 47.33)$ \\
\hline & Kabul ederim & $132(\% 44.00)$ \\
\hline & Cevap yok & $26(\% 8.67)$ \\
\hline \multirow{3}{*}{$\begin{array}{l}\text { 32. Anestezistinizi ameliyat öncesi kendiniz } \\
\text { seçmek ister miydiniz? }\end{array}$} & Evet & $148(\% 49.33)$ \\
\hline & Hayır & $135(\% 45.00)$ \\
\hline & Cevap yok & $17(\% 5.67)$ \\
\hline
\end{tabular}

